\title{
The genus Boesenbergia (Zingiberaceae) in Myanmar with two new records
}

\author{
J.D. Mood ${ }^{1}$, N. Tanaka ${ }^{2}$, M.M. Aung ${ }^{3} \&$ J. Murata ${ }^{4}$ \\ ${ }^{1}$ Lyon Arboretum, University of Hawaii, 3860 Manoa Road, \\ Honolulu, HI 96822, USA \\ ${ }^{2}$ Department of Botany, National Museum of Nature and Science, \\ Amakubo 4-1-1, Ibaraki 305-0005, Japan \\ ${ }^{3}$ Forest Research Institute, Forest Department, Ministry of Natural Resources \\ and Environmental Conservation, Yezin, Nay Pyi Taw, Myanmar \\ ${ }^{4}$ Botanical Gardens, Graduate School of Sciences, the University of Tokyo, 3-7-1, \\ Hakusan, Bunkyo-ku, Tokyo 112-0001, Japan
}

\begin{abstract}
The taxonomic history of Boesenbergia Kuntze (Zingiberaceae) in Myanmar is reviewed. Based on specimen records eight species are currently confirmed as occurring in Myanmar. These include two new records, Boesenbergia albomaculata S.Q.Tong and B. kerrii Mood, L.M.Prince \& Triboun. Two previously listed species, Boesenbergia plicata (Ridl.) Holttum and B. thorelii (Gagnep.) Loes., are not considered here due to lack of specimens originating in Myanmar. A key to the species is provided with a description of each based on living material.
\end{abstract}

Keywords. China, Gastrochilus, Lao P.D.R., Malaysia, Thailand

\section{Introduction}

The genus Boesenbergia Kuntze (Zingiberaceae), first described under the name Gastrochilus Wall. (Wallich, 1829), has its taxonomic origins in Myanmar with the description of two species, B. longiflora (Wall.) Kuntze and B. pulcherrima (Wall.) Kuntze. These were collected from the Rangoon area (Yangon) during an expedition by Nathaniel Wallich and his collector, William Gomez, in 1826. At the time, Wallich's initiative to name a new genus was a bold step forward as some botanists of the day, such as William Roxburgh, might well have classified these new taxa as Alpinia L. Initially, Wallich did follow this thinking when he annotated his specimens as "Alpinia bicristata no. 131" [G. pulcherrima, Wallich 6588 (K-W)] and "Alpinia? calceolaris" [G. longiflora, Wallich $6589(\mathrm{~K}-\mathrm{W})]$. In his circumscription of the new genus (Wallich, 1829) he considered it to be "intermediate" between Alpinia and Kaempferia. Today, molecular phylogenetic data shows that Alpinia is in a different evolutionary lineage, while Kaempferia has a close affinity to Boesenbergia and is in the same tribe, Zingibereae (Kress et al., 2002).

A year after these first discoveries, Gomez found yet another Boesenbergia in the Tavoy area (Tenasserim Division), south of Rangoon. Wallich never described this specimen but did include it in Wallich (1832) as Gastrochilus parvula Wall. [Gomez in 
Wallich $6590(\mathrm{~K}-\mathrm{W})]$. Nearly 60 years later, it was finally described by Baker (1890) in the Flora of British India under Wallich's name, but soon thereafter was changed to Boesenbergia parvula (Wall. ex Baker) Kuntze (Kuntze, 1891).

The first mention of Boesenbergia in a checklist of the plants of Myanmar was published by Lace (1912) with later revisions by Rodger (1922), Hundley \& U Chit Ko Ko (1961), Hundley (1987) and Kress et al. (2003). This last compilation was based on original work plus collections in Myanmar by Kress and staff of the Smithsonian Institution in 1996-2004. Six species of Boesenbergia were listed: B. longiflora (under Curcumorpha longiflora (Wall.) Rao \& Verma), B. parvula, B. plicata (Ridl.) Holttum, B. pulcherrima, B. rotunda (L.) Mansf., and B. thorelii (Gagnep.) Loes.

During one of the Smithsonian expeditions in 2002, a Boesenbergia taxon was found in Kachin State near the Indian border at c. $200 \mathrm{~m}$ (Kress, W.J. et al. 027056 \& 02-7065 (US)), Living plants of these grown at the Smithsonian Greenhouses (GH2000-061 \& GH2000-23I) were later identified by the first author as Boesenbergia albomaculata S.Q.Tong. Three years later this species was found again, this time in the Hukaung Valley Tiger Reserve near Shingbwiyang, Kachin State (Murata, J. et al $20050595 \mathrm{~K}$ (TNS, TI)). Living plants were accessioned and grown to flowering at the Botanical Gardens, The University of Tokyo.

In 2013 three new species were described from Thailand (Mood et al., 2013): Boesenbergia kingii Mood \& L.M.Prince, B. maxwellii Mood, L.M.Prince \& Triboun, and $B$. kerrii Mood, L.M.Prince \& Triboun. In the paper, specimens and living plants of the first two were also documented for Myanmar, while the third species was found by the second author in the Tanintharyi Region of Myanmar in 2015.

In order to verify the current checklist of Boesenbergia species (Kress et al., 2003) and document their representative specimens, the following herbaria were checked: AAU, ASSAM, BK, BKF, C, CAL, E, K, L, MBK, P, RAF, RANG, SING, TI, TNS, and US (Thiers, continuously updated). No specimens from Myanmar could be found for either Boesenbergia plicata or B. thorelii. The former is a robust plant found south of the Isthmus of Kra in the southern provinces of Thailand and also Peninsular Malaysia. It occurs in wet forests on non-calcareous soils. Since similar habitats occur in Tanintharyi Region, it might eventually be found there. The latter species is not likely to occur in Myanmar, as it is a deciduous forest species found on sandstone from the drier, eastern provinces of Thailand and the adjoining western areas of the Lao P.D.R. As the morphology of Boesenbergia thorelii is very similar to B. pulcherrima, it is most likely that a specimen of this was mistaken for $B$. thorelii. Consequently, Boesenbergia plicata and B. thorelii are excluded here from further consideration.

The presence of Boesenbergia rotunda in Myanmar is well documented via numerous specimens, old and new. Its morphology can vary considerably between populations. It is quite common naturally and also in cultivation.

The discoveries of Boesenbergia albomaculata (Kress, W.J. et al. 02-7065 (US); Murata, J. et al. 20050595 (TNS, TI)) and B. kerrii (Tanaka, N. et al. 141 (TNS, RAF)) constitute two new records for Myanmar, bringing the total number of Boesenbergia species to eight based on verified specimens. These are enumerated 
below with a dichotomous key, individual descriptions based primarily on living plants, and photography.

Key to Boesenbergia species in Myanmar

1a. Inflorescence radical 2

1b. Inflorescence arising on top of a leafy shoot ....

2a. Labellum various shades of yellow with red maculate or streaked patterns ........ 3

2b. Labellum pure white with either red or red and violet patterns ........................... 4

3a. Floral tube $12-14 \mathrm{~cm}$ long, labellum $3.8-4 \mathrm{~cm}$ long 2. B. kerrii

3b. Floral tube to $10 \mathrm{~cm}$ long, labellum $2.2-2.5 \mathrm{~cm}$ long 4. B. longiflora

4a. Rhizomes running, pseudostems well-spaced 3. B. kingii

4b. Rhizomes non-running, pseudostems tufted 5. B. maxwellii

5a. Stems branched 6. B. parvula

5b. Stems unbranched 6

6a. Inflorescence at the terminus of a c. $50 \mathrm{~cm}$ stem 7. B. pulcherrima

6b. Inflorescence not as above 7

7a. Inflorescence flabellate to $8 \mathrm{~cm}$ long, anther curved, crested 8. B. rotunda

7b. Inflorescence oblong or oblanceolate, to $29 \mathrm{~cm}$, anther straight, uncrested

1. B. albomaculata

1. Boesenbergia albomaculata S.Q.Tong, Acta Phytotax. Sin. 24: 323 (1986). -TYPE: China, Yunnan, November 1984, Tong, S.Q. \& Liao, W.D. 24852 (holotype HITBC!). (Fig. 1A-D, 2A-B)

Evergreen perennial herb to $70 \mathrm{~cm}$ tall. Rhizome elongate, c. $7-8 \mathrm{~cm}$ long, $1.5-2 \mathrm{~cm}$ wide, externally brown, internally white, without tuberous roots. Stem erect, up to 24 $\mathrm{cm}$ tall, composed of 1-3 leaf sheaths; leafless sheaths 1-2 at the base, longitudinally ridged, red or green, glabrous, margin membranous, translucent. Leaves 1-2; leaf sheaths 2-4, red or green, glabrous; ligule slightly bilobed, lobes an extension of the membranous margin, white, glabrous; petiole $13-20 \mathrm{~cm}$, deeply channelled, green or red, glabrous; lamina ovate, sometimes elliptic, 20-26 ×9-16 cm, adaxially dark green, glabrous, abaxially lighter green, sometimes reddish, especially on young leaves, glabrous, base rounded, truncate or slightly cordate, rarely cuneate, apex acute to acuminate. Inflorescence terminal, to $29 \mathrm{~cm}$ long, exserted from the leaf sheaths; peduncle 5-15 cm long, light green, reddish or white, glabrous, basal sheaths 1-2, 
green or reddish green, glabrous; spike oblong to oblanceolate, 7-12 cm long, c. 2 $\mathrm{cm}$ wide; bracts 8-12, distichous, ovate to lanceolate (flattened), to $5 \mathrm{~cm}$ long, to 2.5 $\mathrm{cm}$ wide, green or red, apex falsely pungent to acute, tightly appressed or forming a pouch, rachis covered; bracteole tubular, lanceolate (flattened), open to the base, to $2.5 \times 1.5 \mathrm{~cm}$, reddish, translucent, glabrous, apex bidentate. Flowers to $6 \mathrm{~cm}$ long; calyx tubular, to $7 \mathrm{~mm}$ long, $5 \mathrm{~mm}$ wide (opened, flattened), red tinged or greenish, mostly translucent, glabrous, apex bifid; floral tube to $4 \mathrm{~cm}$ long, to $3 \mathrm{~mm}$ wide at the base, red, white, or both, externally and internally glabrous; dorsal corolla lobe oblong, to $2.2 \mathrm{~cm}$ long, to $1.2 \mathrm{~cm}$ wide, pink or white, glabrous, margins involute, apex sometimes emarginate, lateral corolla lobes oblong, to $2.4 \mathrm{~cm}$ long, to $1 \mathrm{~cm}$ wide, pink or white, glabrous, margins involute; androecial cup to $1 \mathrm{~cm}$ long, to $8 \mathrm{~mm}$ diam. at the top, oriented $90^{\circ}$ to the floral tube, white, throat mostly glabrous; labellum saccate, orbicular, to $4 \mathrm{~cm}$ long, to $3.8 \mathrm{~cm}$ wide (when flattened), colour either rosy-red from the throat spreading outwards to the margins/apex, with some interior white patches and the exterior sometimes covered with glandular hairs, or colour overall white with dark red throat and centre with lighter red markings, externally with few glandular hairs, internally glabrous, margin entire, revolute at the margins, crisped, crenulate or slightly wavy, apex emarginate; lateral staminodes obovate, to $2 \times 1.5 \mathrm{~cm}$, white, dorsal surface glabrous or with numeous glandular hairs, ventral surface glabrous, apex rounded, revolute. Stamen to $1.7 \mathrm{~cm}$ long, filament to $8 \mathrm{~mm}$ long, 1.7-1.8 $\mathrm{mm}$ wide at the base, white, few glandular hairs; anther $8-9 \times$ c. $3.5 \mathrm{~mm}$, thecae c. $7 \times 2 \mathrm{~mm}$ each, white, dehiscent for full length, axially rotating $180^{\circ}$ at maturity. Ovary ellipsoid, c. 5 $\mathrm{mm}$ long, c. $4 \mathrm{~mm}$ wide, white, glabrous; style filiform, white, glabrous, stigma funnelshaped with 2 opposite teeth on the margin, white, ostiole non-ciliate, sticky liquid produced at maturity; epigynous glands 2, linear, c. $5 \mathrm{~mm}$ long, light yellow. Fruit ellipsoid, green when young. [Composite description using: Tong (1986), living plants of Murata, J. et al. 20050595, and Kress, W.J. et al. 02-7056].

Distribution. China, Myanmar.

Ecology \& phenology. Found in subtropical evergreen forests with high seasonal rainfall. Photographs of ex situ living collections show flowering in December-January and May-August. This species has a two-day flower. On the first day the anther thecae are held together, clasping the style and stigma. Soon after the flower opens, the thecae dehisce along their full length, dropping pollen onto the labellum. On the second day, the thecae begin to rotate radially, reaching c. $180^{\circ}$ from their original position. This action releases the style, allowing the stigma to move downward from the anther. Soon afterwards a viscous drop appears from the ostiole increasing the opportunity for pollen adhesion. Later in the second day, the flower closes, but usually remains attached into the third day when it drops.

Additional specimens examined. CHINA: Yunnan: Jiedaocun, $26^{\circ} 44^{\prime} \mathrm{N} 97^{\circ} 33^{\prime} \mathrm{E}, 240 \mathrm{~m}$ asl, 4 Nov 1974, Tao, G.D. 13163 (HITBC!); Xishuangbanna, cultivated, 25 Nov 2000, Kress, W.J. et al. 00-6815 (US!). 

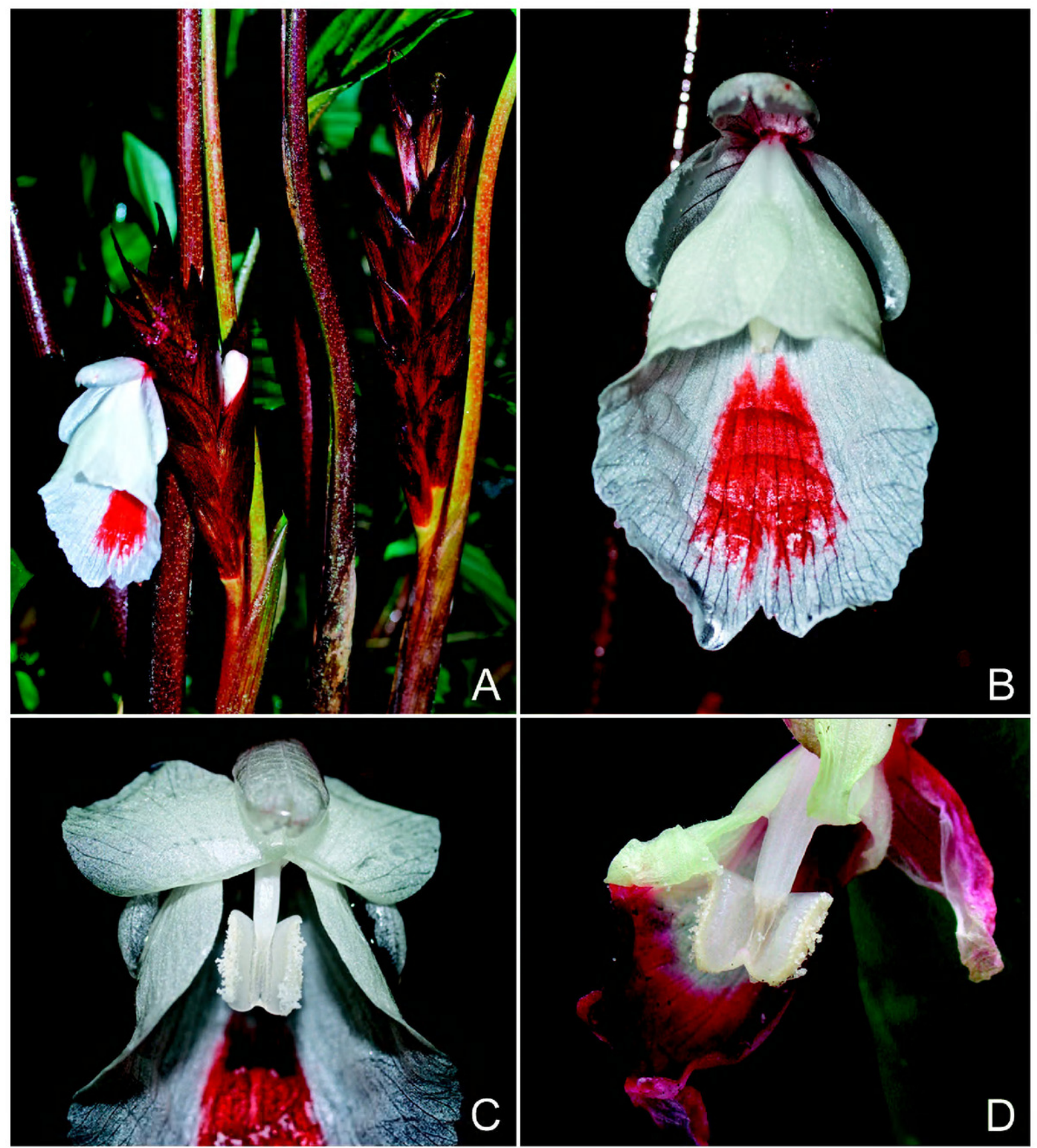

Fig. 1. Boesenbergia albomaculata S.Q. Tong. A, B. Inflorescence and flower. C. Secondday flower showing rotated thecae. D. Second-day flower showing rotated thecae. A-C from Murata, J. et al. 20050595; D from Kress, J.W. 02-7056. (Photos: A-C, J. Mood; D, L.E. Brothers, Dept. of Botany, (C) Smithsonian Institution)

MYANMAR. Kachin State: Tawa Hka (River), $5 \mathrm{~km}$ from Shin Bway Yang toward Pansaung

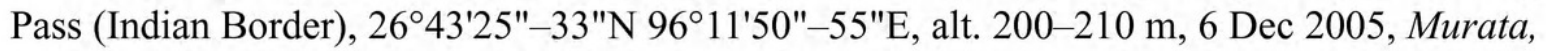
J. et al. 20050595 (TI, TNS!); Myitkyina Township, 240 m, 24 Feb 2002, Kress, W.J. et al. 027056 (US!), ibidem, Kress, W.J. et al. 02-7065 (US!). 
Notes. Currently, this species is only documented in Myanmar from the northwest area of Kachin State with one collection near Shin Bway Yang (Murata, J. et al. 20050595) and another in Myitkyina Township (Kress, W.J. et al. 02-7056, 02-7065). These sites are c. $180 \mathrm{~km}$ apart and both have an evergreen forest ecology. The type of the species (Tong, S.Q. \& Liao, W.D. 24852) was collected c. $250 \mathrm{~km}$ from the Murata collection to the southeast in Yunnan Province on the China/Myanmar border in similar forest, as was an earlier specimen in 1974 (Tao, G.D. 13163). More recently (c. 1999) a living collection was made near Yingjiang, Yunnan, c. $30 \mathrm{~km}$ east of the type locality. It was planted at Xishuangbanna Botanical Garden (XTBG), Yunnan, but with no accession number.

When the living collections mentioned above are compared to the protologue (Tong, 1986), they are readily identified as Boesenbergia albomaculata. The diagnostic characters include the overall habit which is that the plant is tall and upright with numerous 1-3-leaved elements; a large, thick, ovate leaf; a long exserted, terminal, oblong-shaped inflorescence with distichous bracts; and a flower with an androecial cup. There are, though, several characters which are variable, such as bract/labellum colouration and the indumentum on the flowers. Briefly, the Murata collection has red bracts, a labellum pure white with a red throat and a single red patch near the apex and wavy margins. The labellum and lateral staminodes are mostly glabrous with only a few glandular hairs. In contrast, the Kress/XTBG collections have green bracts, labellum rosy-red (dark pink) with white near the base, crenulate margins, and an exterior densely covered in glandular hairs. The protologue details red bracts and a labellum coloured similar to the Kress/XTBG collections, but with no mention of glandular hairs.

2. Boesenbergia kerrii Mood, L.M.Prince \& Triboun, Gard. Bull. Singapore 65: 64, t. 8, 9, 17, 19B (2013). - TYPE: Thailand, Tak Province, 1 November 2012, Mood, J. \& Triboun, P. 12 P170 (holotype BK!). (Fig. 2C-D)

Deciduous herb to c. $1.2 \mathrm{~m}$ tall. Rhizome globular, c. $1 \mathrm{~cm}$ diam., externally red, pink or light tan, internally light yellow to white; many, miniature rhizomes at the base of the stem, c. 5-10 mm long, pink turning red, easily detached; roots fleshy, few to numerous, c. $12 \times 0.5-0.8 \mathrm{~cm}$, tapering to a point, apex rarely expanded, externally and internally white, few fibrous roots, c. $1 \mathrm{~cm}$ long, white, thin. Stem to c. $4 \mathrm{~cm}$ long, c. $0.7 \mathrm{~cm}$ diam., white, glabrous, covered by 5-6 leaf sheaths forming a pseudostem, c. $30 \mathrm{~cm}$ long; leafless sheaths 1-2, green. Leaves 5-8; leaf sheaths to c. $44 \mathrm{~cm}$ long, green or reddish, glabrous; ligule bilobed, to c. $2 \mathrm{~mm}$, lobes an extension of the hyaline margin, green, glabrous; petiole 9-27 cm long, deeply channelled, green, glabrous; lamina elliptic or ovate, $41-61 \times 20-21 \mathrm{~cm}$, base rounded to cordate, sometimes oblique, apex acute to long acuminate, adaxially dark green, glabrous, abaxially lighter green, slightly pubescent or glabrous. Inflorescence radical, 3-6 or more per stem, 3-6 flowers each; peduncle 1-4 cm long, white, glabrous, basal sheaths 1-2, pink and white, covered with short hairs; spike horn-shaped, 5-12 cm long, 1-2 cm diam.; 


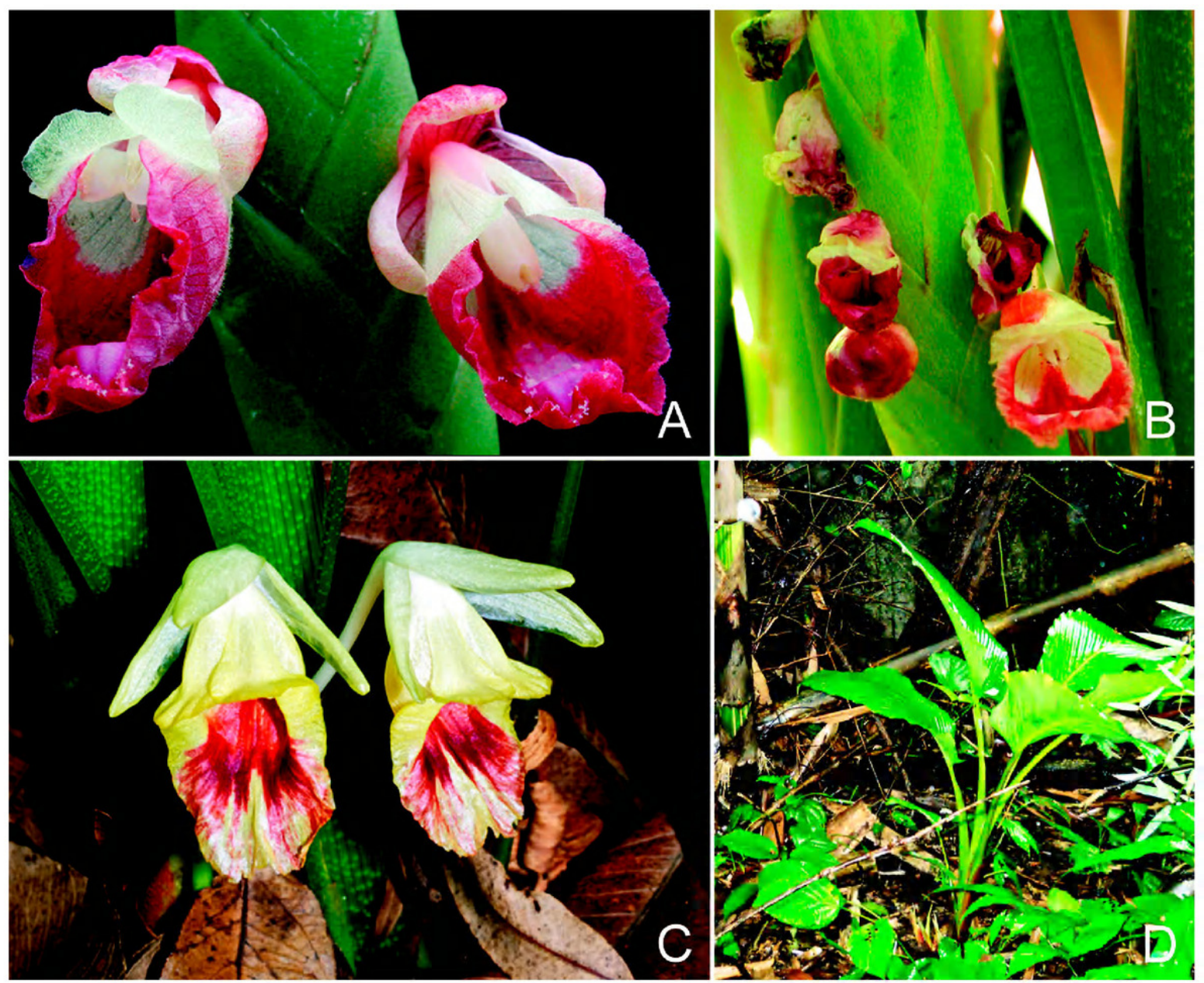

Fig. 2. A, B. Boesenbergia albomaculata S.Q. Tong. C, D. Boesenbergia kerrii Mood, L.M. Prince, \& Triboun. A from Kress, J.W. 02-7056; B from Kress, J.W. 00-6815; C \& D from Mood, J. \& Triboun, P. 12P170. (Photos: A \& B, L.E. Brothers, Dept. of Botany, (C) Smithsonian Institution; C \& D, J. Mood)

bracts 4-6, cymbiform, distichous, 5-6 cm long, white (below ground), green and red (above ground), apex curved; bracteole lanceolate, c. $5 \times 0.5 \mathrm{~cm}$, white, translucent, glabrous. Flowers c. $16 \mathrm{~cm}$ long; calyx tubular, $20 \times 5 \mathrm{~mm}$, white, translucent, apex bidentate; floral tube 12-14 cm long, c. $3 \mathrm{~mm}$ diam., white, glabrous; corolla lobes linear to lanceolate, c. $2 \times 0.5 \mathrm{~cm}$, white to light yellow, mostly glabrous, margins involute; androecial cup 4-5 mm long, oriented $90^{\circ}$ to the floral tube, throat glabrous; labellum saccate, semi-orbicular, $3.8-4 \times 2.2 \mathrm{~cm}$, light yellow, throat centre orangered, maculate with yellow showing through as dots, c. $5 \mathrm{~mm}$ wide at base, broadening toward the margins, ending c. $10 \mathrm{~mm}$ short of the apex, then dark red streaks to the apex, margin entire, revolute on the sides, apex shortly to deeply bilobed, lobes 2-8 $\mathrm{mm}$ long, slightly wavy; lateral staminodes obovate, c. $1.3 \times 1 \mathrm{~cm}$, light yellow, apex rounded, revolute, margin wavy, dorsal surface with few glandular hairs; Stamen c. $1.1 \mathrm{~cm}$ long, scattered glandular hairs full length, apex slightly bilobed, filament $2 \times 2$ $\mathrm{mm}$, light yellow; anther c. $9 \times 3 \mathrm{~mm}$ (first day), c. $6 \mathrm{~mm}$ wide (second day), thecae 
c. $9 \times 1 \mathrm{~mm}$ each, light yellow, dehiscent along the edge for full length, anther crest absent. Ovary cylindrical, c. $8 \times 4 \mathrm{~mm}$, white, glabrous; style filiform, c. $16 \mathrm{~cm}$ long, yellowish-white, glabrous; stigma semi-spherical, ostiole round, non-ciliate, exuding a sticky liquid on the second day; epigynous glands 2, c. $5 \mathrm{~mm}$ long, light yellow. Fruit not seen.

Distribution. Myanmar, Thailand.

Ecology \& phenology. Semi-deciduous forest on or around limestone outcrops. Flowering from June to October with a two-day flowering cycle for each flower.

Additional Myanmar specimens examined. Tanintharyi Region: Mainmapan, Taninthayi

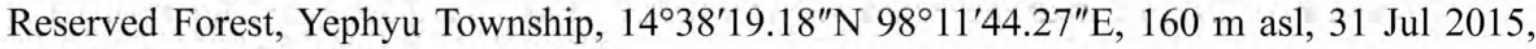
Tanaka, N. et al. 141 (RAF, TNS!).

Notes. Boesenbergia kerrii is similar to B. longiflora, but the former has a more exserted, longer floral tube, broader, longer lip with a truncate apex, and a different labellum colour pattern. When the currently known habitats of each are compared, Boesenbergia kerrii is found only on or around limestone, while the type of $B$. longiflora and the specimen Kress, W.J. 03-7305 (US) were collected on sandstone or shale derived soils.

3. Boesenbergia kingii Mood \& L.M.Prince, Gard. Bull. Singapore 65: 76, t. 14, 15 , 18, 19E (2013). - TYPE: Thailand, Kanchanaburi Province, 1 November 2012, Mood, J. \& Vatcharakorn, P. 12 P173 (holotype BK!). (Fig. 3A-B)

Deciduous herb to c. $1.2 \mathrm{~m}$ tall. Rhizomes numerous, horizontal runners, variable in length, $0.5-1.5 \mathrm{~cm}$ diam., multiple nodes, externally pink or red when young, orange or red when mature, internally yellow to orange; roots few, c. $6 \mathrm{~cm}$ long, 3 $\mathrm{mm}$ diam., exterior orange or white, fibrous roots few, c. $5 \mathrm{~mm}$ long, white. Stem to $1 \mathrm{~cm}$ long, $4 \mathrm{~mm}$ diam., white, glabrous, covered by 3-7 leaf sheaths forming a pseudostem, c. $30 \mathrm{~cm}$ long; leafless sheaths $1-2$, reddish, c. $4 \mathrm{~cm}$ long, ribbed. Leaves 3-7; leaf sheaths to c. $40 \mathrm{~cm}$ long, green or reddish, glabrous; ligule bilobed, c. $4 \mathrm{~mm}$ long, lobes triangular, greenish, glabrous; petiole to c. $20 \times 1 \mathrm{~cm}$, deeply channelled, green or red, glabrous; lamina elliptic $40-45 \times 15-16 \mathrm{~cm}$, base rounded to cordate, apex acute to attenuate, adaxially dark green, glabrous, abaxially lighter green, red or purple, glabrous or slightly pubescent. Inflorescence radical, 3-10 per stem, 4-5 flowers each; peduncle $1-3 \times 0.5-1 \mathrm{~cm}$, white or pink, glabrous, basal sheaths 1-2, 4-6 × 1.5-2 cm, red; spike cylindrical, slightly asymmetrical, 11-14 cm long, 1-1.5 $\mathrm{cm}$ diam.; bracts 4-5, distichous, linear, 6-11 $\times 1.5-2 \mathrm{~cm}$, veined, white, green or red, glabrous; bracteole lanceolate, $5-6 \times 0.5 \mathrm{~cm}$, white, translucent, glabrous, apex bidentate. Flowers 14-15(-20) cm long; calyx 2-2.3 cm long, $5 \mathrm{~mm}$ diam., white, translucent, apex tridentate; floral tube 10-15 cm long, $4 \mathrm{~mm}$ diam., white, tinged 


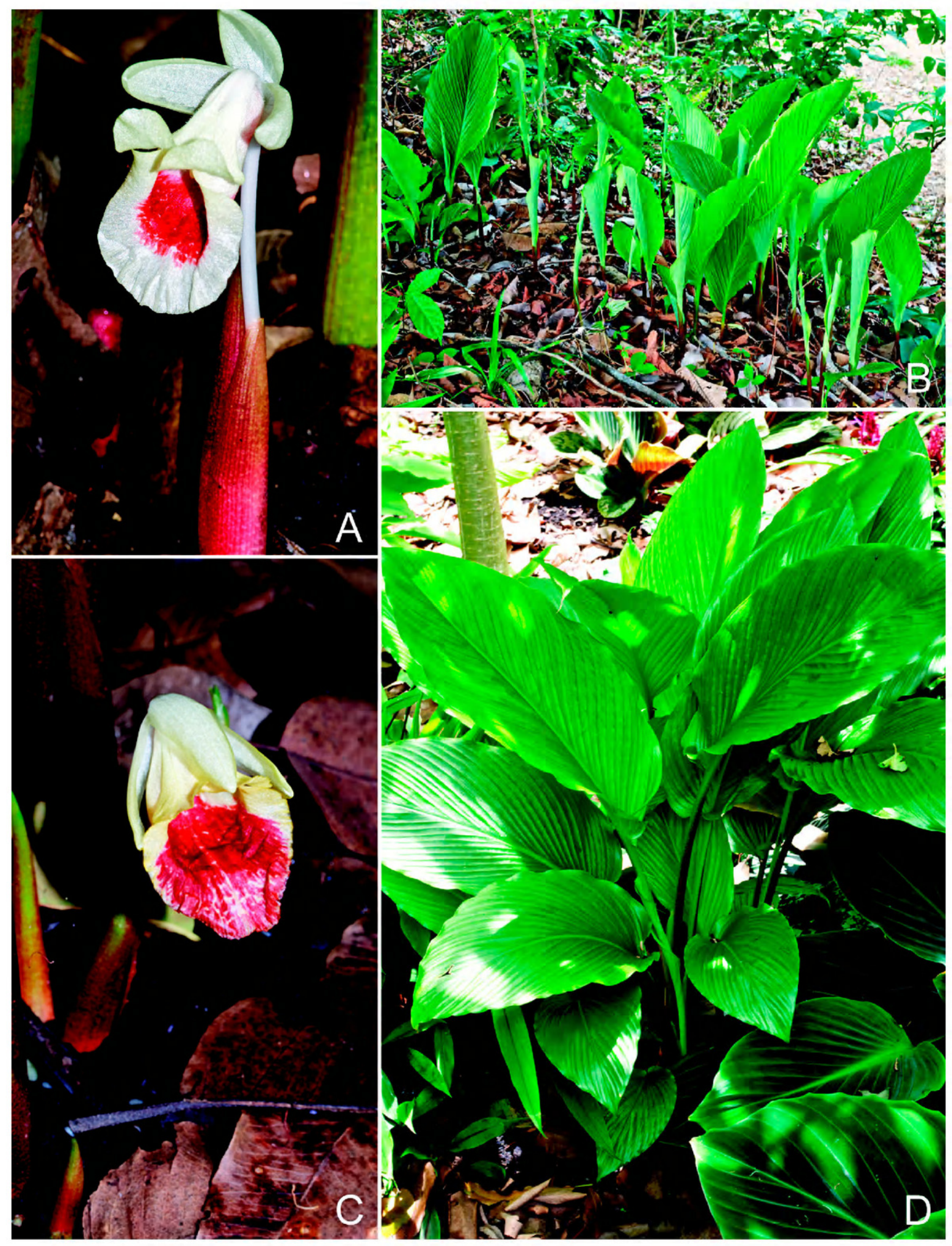

Fig. 3. A, B. Boesenbergia kingii Mood \& L.M. Prince. C, D. Boesenbergia longiflora (Wall.) Kuntze. A \& B from Mood, J. \& Vatcharakorn, P. 12P173; C \& D from Kress, W.J. 03-7305. (Photos: J. Mood) 
or striped pink, glabrous; dorsal corolla lobe oblong, $3.8-4 \times 1.2 \mathrm{~cm}$, creamy-white, glabrous, margins involute, lateral corolla lobes oblong, 3.5-4 × 1.1-1.4 cm, creamywhite, glabrous; androecial cup 10-12 mm long, oriented $45^{\circ}$ to the floral tube, throat glabrous; labellum slightly saccate, broadly oval, $5-6 \times 2.5-2.7 \mathrm{~cm}$, white to creamy-white, throat centre bright red, maculate with white showing through as dots, colour broadening outward to c. $8 \mathrm{~mm}$ short of the apex, margin wavy, wrinkled, apex entire, abaxially with few glandular hairs; lateral staminodes obovate, c. $2.5 \times 1.5 \mathrm{~cm}$, creamy-white, abaxially with few glandular hairs, apex revolute. Stamen c. $1.2 \mathrm{~cm}$ long, glabrous; filament 3-4 × 2-3 mm, white, glabrous; anther $8-9 \times 3 \mathrm{~mm}$ (first day), c. $8-9 \times 5 \mathrm{~mm}$ wide (second day), thecae $9 \times 1 \mathrm{~mm}$ each, white, dehiscent along the edge for full length, anther crest absent. Ovary cylindrical, c. $7 \times 3 \mathrm{~mm}$, white, glabrous; style filiform; stigma elongate, ostiole rectangular, non-ciliate, exuding a sticky liquid on the second day; epigynous glands 2, linear, c. $8 \mathrm{~mm}$ long, white. Fruit not seen.

Distribution. Bangladesh, China, India, Lao P.D.R., Myanmar, Thailand.

Ecology \& phenology. Found in tropical to subtropical evergreen or semi-deciduous forest, often in alluvial soils near streams or in disturbed forest areas and margins. Flowers from May to September with a two-day flowering cycle for each flower.

Additional Myanmar specimens examined. Mandalay Region: Maymyo Hills, Jun 1888, Khan 50 (CAL!); Kyaukpadaung Township, Mt. Popa Park, 17 May 1996, Kress, W.J. 96-5646(US!). Sagaing Region: Katha Dist., Pile R.F., 20 Aug 1915, Rogers, C. 991 (CAL!); Kani Township, Alaungdaw Kathapa National Park, 17 Jul 1997, Kress, W.J. 97-5821 (US!); Kani Township, Magu Range, along Ngabwe Stream, 370 m, 13 Apr 2000,. Kress, W.J. 00-6646 (US!); Kani Township, Alaungdaw Kathapa N.P., 470 m, 15 Apr 2000, Kress, W.J. 00-6661 (US!). Shan State: 45 miles east of Pyin-Oo-Lwin, 630 m, 26 Jun 2003, Kress, W.J. 03-7366 (US!).

Notes. This species is a prolific runner with a mass of rhizomes from $5-10 \mathrm{~mm}$ diameter. In some areas of NE India it has been observed to spread into large populations from a single plant. This was noted on C. Rodgers 991 (CAL) collected in the Sagaing Division: "prevents natural regeneration of teak (Tectona grandis L.f.)". This aggressive rhizome system is believed to be the primary reason for its wide distribution from Sikkim, India to the Lao P.D.R. The flower is the largest yet recorded in Boesenbergia with a floral tube length to c. $16 \mathrm{~cm}$. The flower colour on the type is white with a bright red throat, but there are numerous variations with known hybrids (Mood et al., 2013).

4. Boesenbergia longiflora (Wall.) Kuntze, Revis. Gen. P1.2: 685(1891).-Gastrochilus longiflorus Wall., Pl. Asiat. Rar. 1: 22, t. 25 (1829) (“longiflora"). - Curcumorpha longiflora (Wall.) A.S.Rao \& D.M.Verma, Bull. Bot. Surv. India 13: 339 (1974). TYPE: Burma, Rangoon, 1827, Wallich, N. 6589A (lectotype K, designated by Mood et al. (2013)). (Fig. 3C-D) 
Deciduous herb up to $1 \mathrm{~m}$ tall. Rhizome small, irregularly shaped, c. $1 \mathrm{~cm}$ diam., externally brown, internally light yellow to white; multiple, small bulb-like rhizomes above the main rhizome, c. $1 \mathrm{~cm}$ long, pink or white; tuberous roots two or more, $\mathrm{c}$. $8 \times 0.5 \mathrm{~cm}$, swelling at the terminus, c. $2 \times 1 \mathrm{~cm}$, externally white or pink, internally white, root hairs few, c. $20 \mathrm{~mm}$ long, thin, white. Stem to c. $1 \mathrm{~cm}$, covered by leaf sheaths forming a pseudostem, base $2-2.5 \mathrm{~cm}$ diam.; leafless sheaths $1-2,1-2 \mathrm{~cm}$ long. Leaves 5-8 per pseudostem; leaf sheaths $10-16 \mathrm{~cm}$, longitudinally ridged, green, glabrous, margin hyaline; ligule slightly bilobed, lobes an extension of the hyaline margin, $2 \mathrm{~mm}$ long, slightly acute, protruding outward, green, glabrous; petiole 9-18 $\mathrm{cm}$, deeply channelled, green, glabrous; lamina elliptic or broadly ovate, 41-61 $\times 20$ $21 \mathrm{~cm}$, plicate, adaxially dark green, glabrous, abaxially lighter green, glabrous with a few hairs on the midrib, base rounded to cordate, sometimes asymmetric, apex acute to long acuminate. Inflorescence radical, c. 3-4 per pseudostem, up to c. $12 \mathrm{~cm}$ long (including peduncle) produced from the side of the rhizome; peduncle 1-3 cm long, white, glabrous, basal sheaths 1-2, pink and white, glabrous; spike horn-shaped, 5-10 $\times 1-2 \mathrm{~cm}$; bracts 3-4, distichous, cymbiform, 5-6 $\times 1.5 \mathrm{~cm}$, red and green, glabrous, each bract enclosing one flower, some basal bracts sterile, apex sometimes curved; bracteole cylindrical, c. $5 \times 0.5 \mathrm{~cm}$, white, translucent, glabrous, open to the base, apex acute. Flowers $2-3$ per inflorescence, up to c. $11 \mathrm{~cm}$ long. Calyx tubular, $20 \times 5 \mathrm{~mm}$, white, translucent, glabrous, apex bidentate; floral tube $10 \mathrm{~cm}$ long, c. $3 \mathrm{~mm}$ wide at the base, white, glabrous externally and internally, dorsal and lateral corolla lobes linear to lanceolate, c. $2 \times 0.5 \mathrm{~cm}$, yellowish-white, glabrous, margins inyolute; androecial cup 4-5 mm long, c. $7 \mathrm{~mm}$ diam. at the top, yellowish-white, glabrous externally and internally; labellum saccate, semi-orbicular, $2.2-2.5 \mathrm{~cm}$ long, $2-2.2 \mathrm{~cm}$ wide (when flattened at broadest point), light yellow, throat centre dark red, maculate with yellow showing through as dots, red pattern broadening to the lip apex, glabrous, margin wavy, wrinkled, revolute on the sides, apex elongate, emarginate; lateral staminodes obovate, c. $1.3 \times 1 \mathrm{~cm}$, light yellow, glabrous, apex rounded. Stamen c. $8 \mathrm{~mm}$ long, filament c. $1 \mathrm{~mm}$ long, c. $2 \mathrm{~mm}$ wide at base, light yellow, few short glandular hairs, anther c. $7 \times 2 \mathrm{~mm}$ (first day) then c. $5 \mathrm{~mm}$ wide (thecae diverging on the second day) apex rounded, anther crest absent, thecae c. $7 \times 1 \mathrm{~mm}$, white, dehiscing along the entire length. Ovary cylindrical, c. $7 \times 3 \mathrm{~mm}$, white, glabrous; style filiform, white, glabrous, stigma rounded, white, ostiole transverse, non-ciliate, exuding a sticky liquid on the second day; epigynous glands 2, linear, c. 4 mm long, light yellow. Fruit not seen.

Distribution. Known only from Myanmar.

Ecology \& phenology. Found in the understorey of primary teak forest. Flowering from May to September with a two-day flowering cycle for each flower.

Additional Myanmar specimens examined. Rakhine State: 12 miles $\mathrm{N}$ of Thandwe toward Taung-Gok, Kress, W.J. 03-7305 (US!); 32 miles N of Sittwe, along road to Mrauk U, N. of Ponnagyun, Kress, W.J. 04-7772 (US!). Yangon Region: Insein District, Myaukhlaing Reserve, evergreen forest, sandy places, 30 m, 11 Jun 1948, Khant, P. 426 (RAF!). 
Notes. This species is similar to Boesenbergia kerrii, B. kingii and B. maxwellii as all three have radical inflorescences produced from the rhizome, but is easily distinguished from the latter two by the yellow flowers. Not much is eurrently known about the species even though it was first collected in 1826. More collections are needed to verify its variation and preferred habitat.

5. Boesenbergia maxwellii Mood \& L.M.Prince, Gard. Bull. Singapore 65: 72, t. 12, 13, 18, 19D (2013). - TYPE: Thailand, Tak Province, 1 November 2012, Mood, J. \& Triboun, P. 12 P172 (holotype BK!). (Fig. 4A-B)

Deciduous herb c. 1-1.5 m tall; rhizome irregular in shape, 1-2 cm diam., externally yellow, internally light violet; roots fleshy, cylindrical, $10-20 \mathrm{~cm}$ long, $0.5-0.8 \mathrm{~cm}$ diam., very numerous, extending downward from the rhizome base, externally white, internally translucent white, core pinkish, the terminus swollen into a sphere, c. $2 \times 3$ cm, root hairs c. $18 \mathrm{~mm}$ long, c. $2 \mathrm{~mm}$ diam., white. $S t e m$ to c. $10 \mathrm{~cm}$, c. $1 \mathrm{~cm}$ diam., white, glabrous, covered by $4-6$ leaf sheaths forming a pseudostem, to c. $30 \mathrm{~cm}$ long; leafless sheaths 1-2, reddish, becoming dry, papery. Leaves 4-6; leaf sheaths to c. $48 \times$ $2.5 \mathrm{~cm}$, green, glabrous, ribbed; ligule bilobed, lobes c. $2 \mathrm{~mm}$, acute; petiole $5-30 \mathrm{~cm}$, light green, glabrous, finely ribbed; lamina elliptic, $33-50 \times 15-25 \mathrm{~cm}$, base rounded to cordate, apex acute, adaxially dark green, glabrous, abaxially lighter green, slightly pubescent or glabrous. Inflorescence radical, 3-10 per stem, attached to the rhizome from below the stem, 4-6 flowers each; peduncle $3-5 \mathrm{~cm}$ long, $0.5-8 \mathrm{~cm}$ diam., white or pink, glabrous, 1-2 basal sheaths, $3.5-4.5 \times 1-1.5 \mathrm{~cm}$; spike horn-shaped, $8-10$ $\mathrm{cm}$ long, c. $2 \mathrm{~cm}$ diam.; bracts 4-6, distichous, cymbiform, white and pink or red; bracteole cymbiform, c. $4 \times 0.5 \mathrm{~cm}$, translucent, glabrous, apex bidentate. Flowers $12-16 \mathrm{~cm}$ long; calyx tubular, c. $3 \mathrm{~cm}$ long, c. $0.5 \mathrm{~cm}$ diam., white, translucent, apex tridentate; floral tube 12-14 cm long, c. $3 \mathrm{~mm}$ diam., white with a pink tinge; dorsal corolla lobe oblong, c. $3.6 \times 1.3 \mathrm{~cm}$, white, glabrous, apex cucullate, margins involute, lateral corolla lobes oblong c. $4.3 \times 1 \mathrm{~cm}$, white, glabrous, apex cucullate, margins involute; androecial cup $10-16 \mathrm{~mm}$ long, oriented c. $45^{\circ}$ to the floral tube, throat glabrous; labellum slightly saccate, broadly oval, $4.5-5 \times 2.7-3 \mathrm{~cm}$, white, abaxially with few glandular hairs, throat orange-red in centre, maculate with white showing through as dots ending at the lip, dark pink band with lighter pink to the apex, surface and margins crisped, apex entire, irregular, revolute; lateral staminodes obovate, c. $2.3 \times 1 \mathrm{~cm}$, pure white, margins irregular, apex revolute, abaxially with few glandular hairs. Stamen c. $12 \mathrm{~mm}$ long; filament c. $3 \times 2 \mathrm{~mm}$, white, few glandular hairs; anther c. $10 \times 3 \mathrm{~mm}$ (first day), c. $10 \times 6 \mathrm{~mm}$ (second day), white, glabrous, thecae c. $10 \times 1$ $\mathrm{mm}$ each, white, dehiscent along the edge for full length, anther crest absent. Ovary cylindrical, c. $7 \times 3 \mathrm{~mm}$, white, glabrous; stigma semi-spherical, ostiole oval, nonciliate, exuding a sticky liquid on the second day; epigynous glands 2, linear, c. $6 \mathrm{~mm}$ long, tan. Fruit cylindrical, c. $15 \times 6 \mathrm{~mm}$, glabrous, white, three longitudinal ridges, calyx and floral tube remain partially intact; seed globular, c. $3 \mathrm{~mm}$ diam., hirsutulous, yellowish-brown, aril white, translucent. 

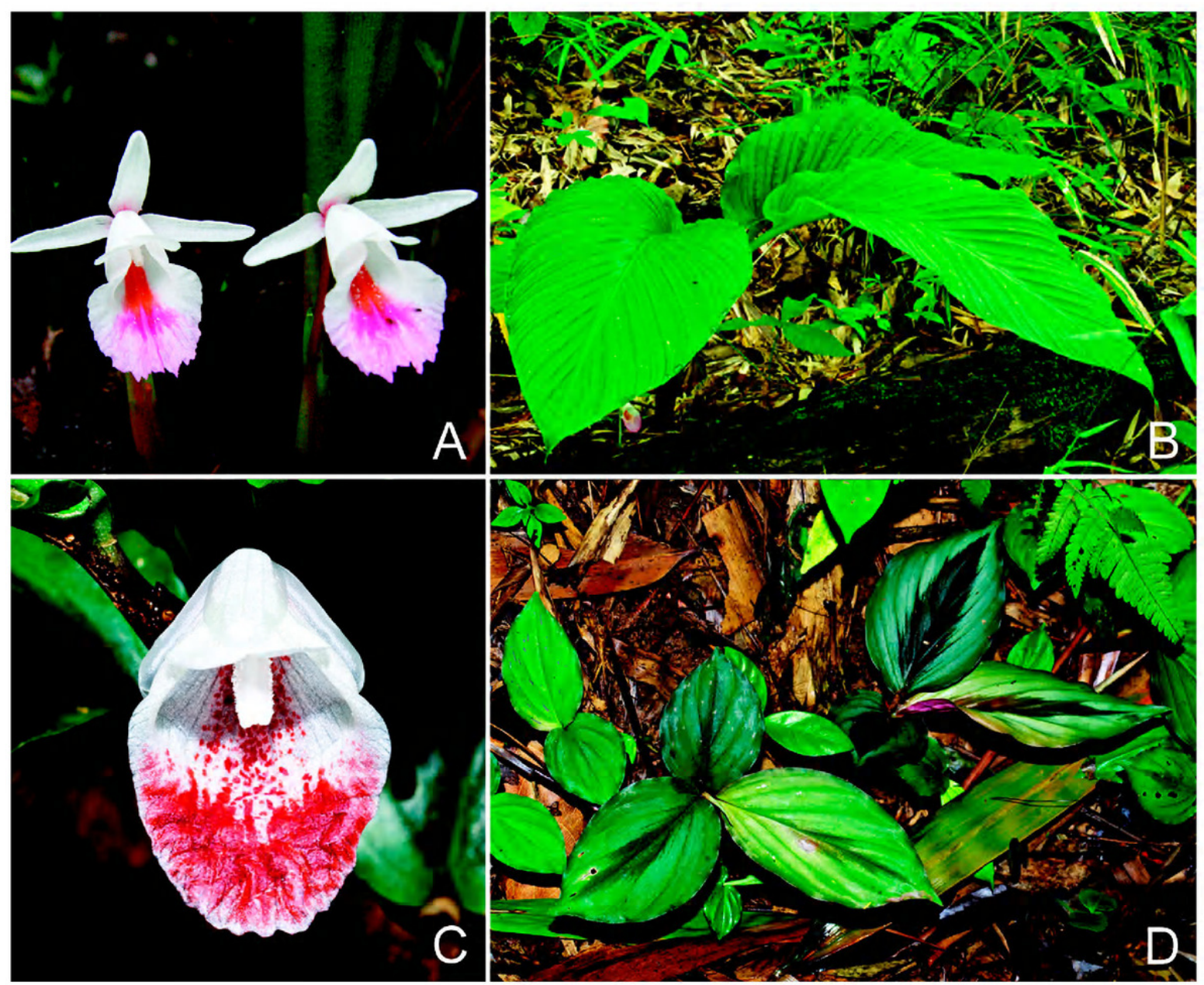

Fig. 4. A, B. Boesenbergia maxwellii Mood \& L.M. Prince. C, D. Boesenbergia parvula (Wall. ex Baker) Kuntze. A \& B from Funakoshi, H. et al. 085387; C \& D from Mood, J. \& Chalermglin, P. 3460. (Photos: A \& B, H. Funakoshi (BRIC, Japan); C \& D, J. Mood)

Distribution. Lao P.D.R., Myanmar, Thailand.

Ecology \& phenology. Found in mountainous areas in tropical evergreen or semideciduous forest. Flowering from May to September with a two-day flowering cycle for each flower.

Additional Myanmar specimens examined. Chin State: Along the roadside, Natma Taung (Mt. Victoria) National Park, Tanaka, N. et al. 023015 (MBK, TI!); between Kampetlet and Saw, $21^{\circ} 11.03^{\prime} \mathrm{N} 94^{\circ} 06.8^{\prime} \mathrm{E}, 760 \mathrm{~m}$ asl, Funakoshi, H. et al. 085387 (MBK, RAF!); Natmataung N.P. above Kampetlet, near guest house, 1635 m, 10 Nov 2004, Kress, W.J. 04-7722 (US!); Natmataung N.P. above Kampetlet, 1635 m, 10 Nov 2004, Kress, W.J. 04-7724(US!). Mandalay Region: Near the Education Center, Mt. Popa, 17 Jun 2000, Khin Myo Htwe 020380 (MBK, TI, herbarium of Education Centre, Popa Mountain Park!). Sagaing Region: Kani Township, Butolong Reserve, 500 m, 16 Jul 1997, Kress, W.J. 97-5817 (US!); Kani Township, Magu Range, along Ngabwe Stream, 370 m, 13 Apr 2000, Kress, W.J. 00-6639 (US!); Kani Township, Magu Range, along Ngabwe Stream, 375 m, 13 Apr 2000, Kress, W.J. 00-6647 (US!). 
Notes. The flower of this species is large and showy with an orange throat and dark pink crinkled lip margin, but many variations in labellum colour pattern and tint have been observed. It is sometimes difficult to distinguish from Boesenbergia kingii from flowers alone as hybrids between the two are known (Mood et al., 2013). Vegetatively, Boesenbergia maxwellii is distinguishable by its clumping, few-stemmed habit and long, vertical, tuberous roots. Also, it tends to grow at higher elevations than Boesenbergia kingii.

6. Boesenbergia parvula (Wall. ex Baker) Kuntze, Revis. Gen. Pl. 2: 685 (1891). Gastrochilus parvulus Wall. ex Baker in Hook.f., Fl. Brit. India 6: 218 ("parvula") (1890). - TYPE: Burma, Tavoy, 1827, Gomez, W. in Wallich, N. 6590 (lectotype K-W!, designated here). (Fig. 4C-D)

Deciduous herb to c. $30 \mathrm{~cm}$, upright to prostrate. Bud-crowned tuberous root, cylindrical, 1-13 cm long, to c. $2 \mathrm{~cm}$ diam., often several attached together at the proximal end, internally and externally white, covered in short roots; roots few, fleshy, to c. $3 \mathrm{~mm}$, fibrous roots few, short. Stems succulent, internodes short, branched from the lower leaf axils; leafless sheaths corrugate, red or green. Leaves alternating along the stem, 5-7, mostly congested near the terminus; leaf sheaths $1-3, \mathrm{c.} .2 \mathrm{~cm}$ long, corrugate, red or green; ligule bilobed, to c. $5 \mathrm{~mm}$, lobes triangular, green; petiole subsessile to c. $2 \mathrm{~cm}$, ribbed; lamina oval, to $10 \times 5 \mathrm{~cm}$, base attenuate, apex acuminate, adaxially green, with or without a darker centre and silver margins, glabrous, abaxially green or reddish, mostly glabrous. Inflorescence terminal on the main stem and axillary stems, tightly clasped between the leaf sheaths, partially exserted, mucilaginous, 3-7 flowers; peduncle to $1 \mathrm{~cm}$ long, white; spike fusiform, to c. $4 \mathrm{~cm}$ long; bracts 3-5, distichous, lanceolate, to c. $3 \mathrm{~cm}$ long, apex acuminate, green or red, covered portions white, glabrous, finely striate; bracteole lanceolate, to $2.5 \mathrm{~cm}$ long, green or white, glabrous. Flowers c. $3 \mathrm{~cm}$ long, oriented $90^{\circ}$ to the bract, deflexed downward; calyx c. $3 \mathrm{~mm}$ long, white, translucent, apex irregular; floral tube $1.5-3.5 \mathrm{~cm}$ long, white, glabrous; dorsal and lateral corolla lobes ovate, c. $10 \times 5 \mathrm{~mm}$, apex cucullate, white, glabrous; androecial cup c. $5 \mathrm{~mm}$ long, oriented c. $90^{\circ}$ to the floral tube, throat with hairs; labellum deeply saccate, nearly orbicular, c. $2.5 \times 2 \mathrm{~cm}$, white with various red patterns, glabrous, apex entire, margins deflexed; lateral staminodes obovate, c. $7 \times$ $5 \mathrm{~mm}$, white, glabrous. Stamen c. $9 \mathrm{~mm}$ long, white, glandular hairs for full length; filament c. $2 \mathrm{~mm}$ long; anther c. $6 \times 3 \mathrm{~mm}$, white, thecae $5 \times 1.5 \mathrm{~mm}$, dehiscent for full length, anther crest absent. Ovary cylindrical, c. $3 \times 2 \mathrm{~mm}$, white, glabrous; style filiform, c. $4 \mathrm{~cm}$ long, white; stigma orbicular, white, ostiole circular, ciliate; epigynous glands 2, linear, c. $2 \mathrm{~mm}$ long, light green. Fruit cylindrical, c. $1.2 \mathrm{~cm}$ long, tan; seed elongate c. $6 \times 2 \mathrm{~mm}$, brown, hirsutulous, aril medusa-form, c. $3 \mathrm{~mm}$ long, white, translucent, funiculus c. $2 \mathrm{~mm}$ diam., white. Bulbils cylindrical, $1-1.5 \times 0.7$ $\mathrm{cm}$, green, sericeous, occurring under the leaf sheaths at stem nodes.

Distribution. Lao P.D.R., Thailand, Vietnam. 
Ecology \& phenology. Found in tropical evergreen or semi-deciduous forest near streams in well shaded areas, often in association with bamboo. This species forms large, spreading populations on hillsides and stream banks where there is good drainage. Flowering occurs from June to September.

Additional Myanmar specimens examined. Shan State: Gokteik Gorge, 450 m, 2 Aug 1908, Lace, J.H. 4163 (E!). Tanintharyi Region: Half mile east of Paungdaw Power station, Aug 1961, Keenan, J. et al 738 (E!); Inland of river east of Paungdaw Power Station, Aug 1961, Keenan, J. et al. 829 (E!); Hills west of Paungdaw Power Station, Keenan, J. et al. 971 (E!); 2.5 miles east of Paungdaw Power Station, Aug 1961, Keenan, J. et al. 1008 (E!); East of Paungdaw Power Station, Sep 1961, Keenan, J. et al. 1399 (E!); Mainmapan, Taninthayi Reserved Forest, Yephyu Township, $14^{\circ} 37^{\prime} 22.63^{\prime \prime} \mathrm{N} 98^{\circ} 08^{\prime} 17.24^{\prime \prime} \mathrm{E}, 17 \mathrm{~m}$ asl., 15 Aug 2015, Tanaka, $N$. et al. 138 (RAF, TNS!); East of Myitta, $176 \mathrm{~m}$ asl, 11 Jul 2014, Mood, J. \& Chalermglin, P. 3460 (BKF!).

Notes. This species is easily distinguished from others currently recorded in Myanmar by its small stature and branched-stem habit. The axillary stems are mostly prostrate and can also flower. The main stem usually has 3-6 leaves toward the stem terminus where a small, few-flowered inflorescence occurs. Often the adaxial lamina surface is variegated with a dark green feathered midrib with silvery green on either side extending almost to the margin. Abaxially the lamina is green or bright wine-red. Plants are almost always found in large populations as they are known to produce bulbils in the leaf axils late in the season prior to dormancy. These help to proliferate the species clonally.

7. Boesenbergia pulcherrima (Wall.) Kuntze, Revis. Gen. Pl. 2: 685 (1891). Gastrochilus pulcherrimus Wall., Pl. Asiat. Rar. 1: 22, t. 24 ("pulcherrima") (1829). -TYPE: Illustration in Wallich, Pl. Asiat. Rar. 1: 22, t. 24 (1829) [lectotype designated by Aishwarya \& Sabu (2015)]. (Fig. 5A-B)

Deciduous herb to c. $70 \mathrm{~cm}$, upright to slightly decumbent, number of stems variable (one or more). Rhizome with multiple elements developing horizontally, spherical, c. $2 \mathrm{~cm}$ diam., externally golden brown, internally white; roots fleshy, swollen, c. $6 \mathrm{~cm}$ long, c. $1 \mathrm{~cm}$ diam., externally and internally white, broadest at the terminus, fibrous roots c. $2 \mathrm{~mm}$ diam., white. Stems to $50 \mathrm{~cm}$, c. $1 \mathrm{~cm}$ diam., semi-rigid, nodes c. 10 $\mathrm{cm}$ apart; leafless sheaths 1-2, c. $12 \mathrm{~cm}$ long, green or reddish, finely ribbed. Leaves alternate, 6-8, leaf sheaths to c. $18 \mathrm{~cm}$ long, finely ribbed, green; ligule bilobed, to $1.5 \mathrm{~cm}$, green becoming papery, glabrous, apices rounded; petiole subsessile, finely ribbed; lamina elliptic, to c. $25 \times 9$, base attenuate, apex acuminate, adaxially with raised veins, dark green, abaxially green or reddish-purple, glabrous. Inflorescence terminal, clasped between the leaf sheaths, partially exserted, c. 15 flowers; peduncle to $1 \mathrm{~cm}$ long, green, glabrous; spike oblong, to $13 \times 1.5 \mathrm{~cm}, \mathrm{c} .1 \mathrm{~cm}$ thick; bracts $\mathrm{c}$. 14 , distichous, lanceolate, c. $5 \times 1.5 \mathrm{~cm}$, radially congested in two rows (one-sided), finely ribbed, light green, papery, sericeous; bracteole elliptic, to c. $3.5 \times 1 \mathrm{~cm}$, white, 
sericeous. Flowers to c. $4 \mathrm{~cm}$ long, oriented c. $135^{\circ}$ to the floral tube; calyx to c. $1 \mathrm{~cm}$, apex mostly entire, white, glabrous; floral tube c. $3 \mathrm{~cm}$ long, white, glabrous; dorsal and lateral corolla lobes elliptic, c. $18 \times 8 \mathrm{~mm}$, white, glabrous, apices cucullate; androecial cup c. $7 \mathrm{~mm}$ long, oriented c. $90^{\circ}$ to the floral tube, throat with hairs; labellum deeply saccate, obovate, c. $3 \times 2 \mathrm{~cm}$, white, throat with two red spots at the base and two parallel red lines broadening outward, the apex longitudinally streaked with red or pink, glabrous, margins entire, apex entire or emarginate, deflexed; lateral staminodes obovate to nearly orbicular, c. $1.3 \times 1.1 \mathrm{~cm}$, white with two red spots at the base, glabrous. Stamen 8-10 mm long, white, glandular hairs for full length; filament c. $2 \mathrm{~mm}$ long; anther 6-7 $64 \mathrm{~mm}$, broader at the apex than at the base, truncate, thecae $6 \times 1 \mathrm{~mm}$, dehiscent for full length, divergent at the apices. Ovary cylindrical, c. $2 \times 2 \mathrm{~mm}$, light green, glabrous; style filiform, c. $4 \mathrm{~cm}$ long; stigma semi-spherical, white, ostiole circular, ciliate; epigynous glands 2, linear, c. $1.5 \mathrm{~mm}$, yellow. Fruit cylindrical, c. $14 \mathrm{~mm}$ long; seed c. $5 \mathrm{~mm}$ long, pubescent, aril white.

Distribution. Lao P.D.R., Myanmar, India, Thailand.

Ecology \& phenology. Found in mountainous areas in tropical evergreen or semideciduous forest, often along streams and in association with bamboo. Flowering from August to November.

Additional Myanmar specimens examined. Bago Region: Taungoo Dist., 4 Aug 1911, Lace, J.H. s.n. (E! [E00389694]); Taungoo Dist., 4 Aug 1911, Lace, J.H. s.n. (E! [00389695] in parte, inflorescence $=\mathrm{cf}$. Cautleya spicata $(\mathrm{Sm}$.) Baker); Paungpyin Township, $400 \mathrm{~m}, 13$ Jul 2002, Kress, W.J. 02-7151 (US!); Paungpyin Township, 400 m, 13 Jul 2002, Kress, W.J. 02-7153 (US!). Chin State: Chin Hills, Jun 1892, Huk, A. s.n. (SING! [0155288]). Kachin State: Metkina, Kachin Hills, Aug 1899, Shaik Mokim 140 (CAL, P!). Tanintharyi Region: Michaung Hlaung (Old village), Tanintharyi Reserved Forest, Yephyu Township, $17 \mathrm{~m}$ alt., 15 Aug 2015, N. Tanaka et al. 154 (RAF, TNS!); Thetkaekawt Compartment, Yephyu Township, $14^{\circ} 20^{\prime} 45.94^{\prime \prime} \mathrm{N} 98^{\circ} 11^{\prime} 28.96^{\prime \prime} \mathrm{E}, 76 \mathrm{~m}$ asl, $N$. Tanaka et al. 171 (RAF, TNS!).

Notes. Three years after Wallich published the protologue, he listed Wallich 6588 (KW) in his Numerical List (Wallich, 1832) as Gastrochilus pulcherrima (Boesenbergia pulcherrima). The specimen is of a mature, flowering plant with a c. $10 \mathrm{~cm}$ long stem including the inflorescence. This size is in stark contrast to the description and accompanying icon (tab. 24). Recently, Aishwarya \& Sabu (2015) lectotypified Plate 24 in Wallich (1829). Prior to this designation, reference to this specimen led to many misidentifications in the herbarium, especially in India and Thailand. It is the first author's opinion that Wallich 6588 most likely represents Boesenbergia parvula as there are no other described species which are similar that are currently found in Myanmar.

In the field, Boesenbergia pulcherrima is easily identified by its c. $50 \mathrm{~cm}$ long stem with leaves on the upper half, short or subsessile petioles, and long, bilobed ligules. 

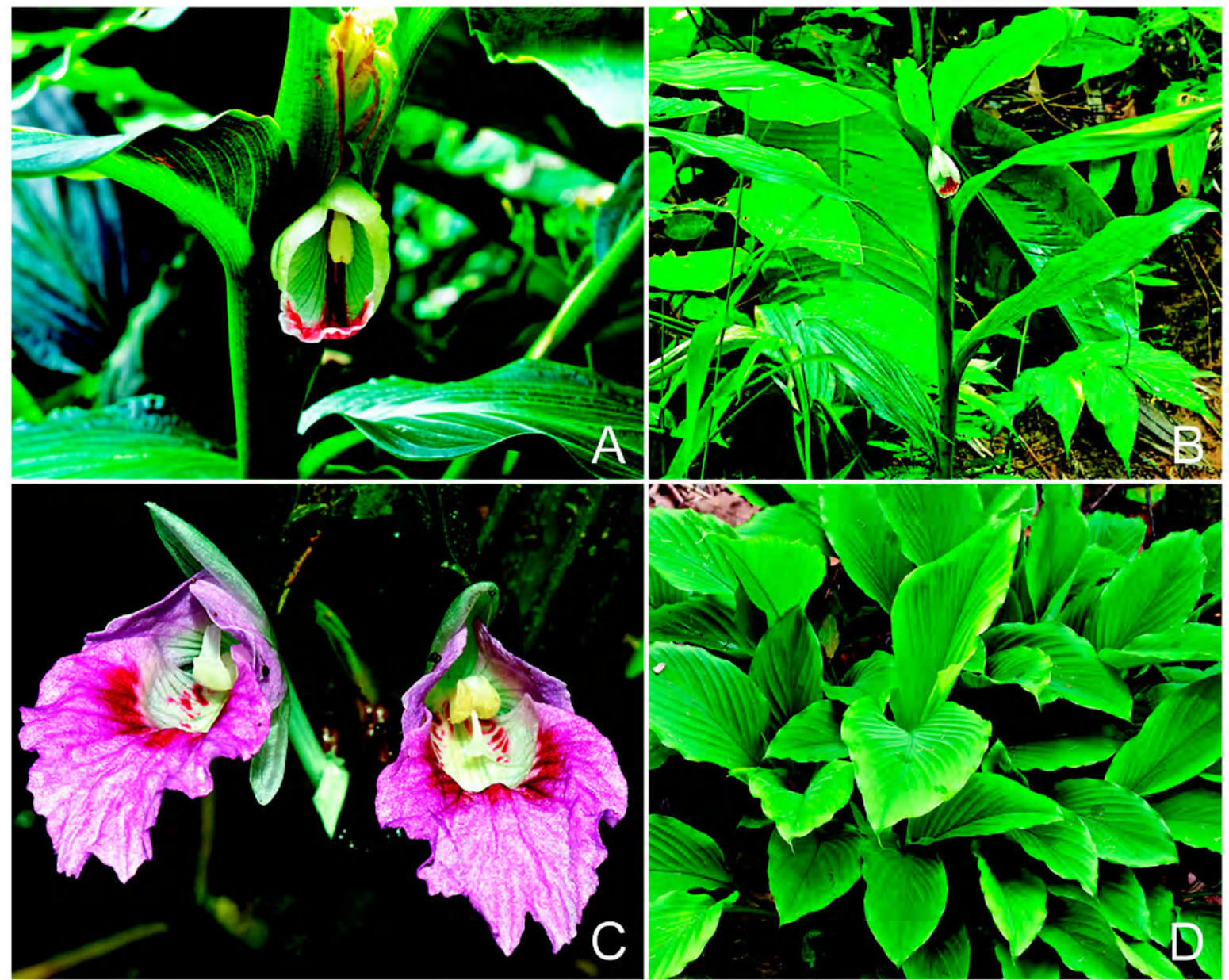

Fig. 5. A, B. Boesenbergia pulcherrima (Wall.) Kuntze. C, D. Boesenbergia rotunda (L.) Mansf. A \& B from Mood, J. \& Vatcharakorn, P. 3363; C \& D from Mood, J. \& Vatcharakorn, P. 3037. (Photos: J. Mood)

Often the abaxial lamina surface is red or purplish. The inflorescence is partially hidden by the two upper leaf sheaths, although may sometimes be more exserted as depicted in the lectotype (icon). The red and white flowers are very similar to Boesenbergia parvula, but larger.

8. Boesenbergia rotunda (L.) Mansf., Kulturpfl. 6: 239 (1958); Veldkamp, Philipp. J. Sci. 142: 215, t. 1-7 (2013). - [Manja-kua Rheede, Hort. Malab. 11: 19, t. 10, (1692), nom. inval, cited by L., Musa Cliff.: 15 (1736] - Curcuma rotunda L., Sp. Pl. 1, 2 (1753). - Kaempferia ovata Roscoe, Trans. Linn. Soc. 8: 351 (1807), nom. nov. propter K. rotundam L. (1753). - Gastrochilus rotundus (L.) Alston, Handb. Fl. Ceylon 6: 281 (1931). -TYPE: Rheede, Hort. Malab. 11: t. 10, (lectotype, designated by Burtt \& Smith (1972)). (Fig. 5C-D)

Zingiber xanthorhizum Moon, Cat. Ceylon 1 (1824), nom. nud. 
Kaempferia pandurata Roxb., Asiat. Res. 11: 328, t. 2 (1810),-Gastrochilus panduratus (Roxb.) Ridl., J. Str. Branch Roy. As. Soc. 32: 110, 114 (1899); Veldk., Philipp. J. Sci. 142: 216, t. 5, 6 (2013). - Boesenbergia pandurata (Roxb.) Schltr. in Fedde, Repert. 12: 316 (1913). -TYPE: Roxburgh, Asiat. Res. 11, t. 2 (1810), designated by Veldkamp, Philip. J. Sci. 142: 216 (2014).

Kaempferia cochinchinensis Gagnep., Bull. Soc. Bot. France 54: 165 (1907). Gastrochilus cochinchinensis (Gagnep.) Valeton, Bull. Jard. Bot. Buitenzorg II, 27: 88 ("cochinchinense") (1918). - Boesenbergia cochinchinensis (Gagnep.) Loes. in Engler \& Prantl, Nat. Pflanzenfam., ed. 2, 15a: 571 (1930). - TYPE: Vietnam ['Cochichine'], Thu-dau-moth, Thorel s.n. (lectotype P [P032700], designated here; isolectotype P [P00686540]).

Deciduous herb to $1 \mathrm{~m}$ tall, upright, variable number of stems per clump. Rhizome with multiple elements developing horizontally and vertically, c. $3 \times 2 \mathrm{~cm}$, externally and internally yellow-orange; roots cylindrical, fleshy, c. $6 \times 1 \mathrm{~cm}$, externally and internally light orange, the lower portion near the terminus thicker, slightly spherical; fibrous roots few. Stems semi-rigid, of variable length and diameter, covered by 4-6 leaf sheaths forming a pseudostem, variable in length; leafless sheaths $1-2$, short, red or green, glabrous. Leaves highly variable in size, shape and colouration, adaxial surface texture rubbery; leaf sheaths extend to the base of the stem forming a pseudostem; ligule, petiole and lamina variable. Inflorescence terminal, 5-10 cm long, clasped between the leaf sheaths, sometimes slightly exserted, c. 10 flowers; peduncle to 2 $\mathrm{cm}$ long, white; spike oblong, to c. $6 \mathrm{~cm}$ long; bracts c. 10, radially congested in two rows (one-sided), lanceolate, c. $3.5 \times 0.5 \mathrm{~cm}$, finely ribbed, light green, glabrous; bracteole elliptic, to c. $3 \times 0.5 \mathrm{~cm}$, white, glabrous. Flowers to c. $6 \mathrm{~cm}$ long; calyx to c. $1.5 \mathrm{~cm}$, apex dentate, translucent, glabrous; floral tube c. $4 \mathrm{~cm}$ long, white, glabrous, with two glands at the filament base; dorsal and lateral corolla lobes oblong, c. 20 $\times 5 \mathrm{~mm}$, white, glabrous; androecial cup absent; labellum shortly spathulate, slightly concave, c. $2 \times 1.5 \mathrm{~cm}$, white with various combinations of red, pink or violet, crisped, apex entire or emarginate; lateral staminodes spathulate, c. $15 \times 5 \mathrm{~mm}$, white with translucent veins, glabrous. Stamen to c. $8 \mathrm{~mm}$ long, white or pinkish, few glandular hairs; filament to 2-3 mm long; anther to 4-5 $\times 1-3 \mathrm{~mm}$, thecae dehiscent for full length, diverging in the upper half. Ovary cylindrical, c. $3 \times 2 \mathrm{~mm}$, white, glabrous; style filiform, to c. $5.5 \mathrm{~cm}$ long; stigma flabellate, white or pink, ostiole oval, ciliate; epigynous glands 2, linear, c. $5 \mathrm{~mm}$, white. Fruit cylindrical, white, glabrous; seed brown.

Distribution. Widespread, wild and cultivated.

Ecology \& phenology. Found in a variety of habitats. Flowering from June to October.

Myanmar specimens examined. Mandalay Region: Pyin-Oo-Lwin Township, $650 \mathrm{~m}, 3 \mathrm{Jul}$ 1999, Kress, W.J. 99-6511 (US!); Thabeikyin Township, 550 m, 11 Jun 2001, Kress, W.J. 01- 
6896 (US!). Sagaing Region: Road $15 \mathrm{mi}$ E of Chindwinn River, $345 \mathrm{~m}, 19$ Jun 2001, Kress, W.J. 01-6935 (US); Kani Township, Alaungdaw Kathapa N.P., 625 m, 15 Jul 1997, Kress, W.J. 97-5804 (US!); Kani Township, Alaungdaw Kathapa N.P., 560, m, 14 April 2000, Kress, W.J. 00-6648 (US!). Shan State: Nawnghkio Township, 25 miles E of Pwin-Oo- Lwin, 730 m, 2 Jul 1999, Kress, W.J. 99-6502 (US!). Tanintharyi Region: Mainmapan, Taninthayi Reserved Forest, Yephyu Township, $14^{\circ} 37^{\prime} 22.63^{\prime \prime} \mathrm{N} 98^{\circ} 08^{\prime} 17.24^{\prime \prime} \mathrm{E}, 17 \mathrm{~m}$ alt., 31 Jul 2015, Tanaka, N. et al. 133 (RAF, TNS!).

Notes. This species occurs as both a wild plant and a cultivated plant due to its medicinal and culinary uses. Its vegetative morphology and labellum form are quite variable throughout its range. Consequently, the description above is a rather general one with many variations to be expected. One floral constant is the anther which is longitudinally curved with a long, deflexed crest. No matter the above ground variation, it seems the subterranean architecture mostly remains the same with long, vertical, orange or yellow "keys" or "fingers" which are adventitious storage roots. This is the only species in Myanmar with a fan-shaped (flabellate) inflorescence and crested anther.

\section{Conclusions}

At this juncture it is recognised that several more Boesenbergia species are likely to be discovered in Myanmar. One probable example is Boesenbergia siphonantha (King ex Baker) M.Sabu et al. which is found in northwest Thailand very close to the Myanmar border. Recently it was added as a new record for Thailand and Vietnam (Mood et al., 2016). One specimen A. Huk s.n., Upper Burma, July 1892 (CAL), cited therein, might be Boesenbergia siphonantha, but that collection is rather poor and cannot be positively determined. Common Peninsular Thai/Malay species such as Boesenbergia curtisii (Baker) Schltr. and B. plicata are also likely to be found in Myanmar when Taninthayi Region is better explored and collected.

ACKNOWLEDGEMENTS. The authors thank Dr Nyi Nyi Kyaw, Director General, Forest Department, and Dr Taung Naing Oo, Director of Forest Research Institute, Forest Department, Myanmar for their arrangement of our field trips; W.J. Kress and M. Bordelon for assistance (US); and T. Ohi-Toma for his arrangement of the samples. This study was partially supported by JSPS KAKENHI Grant Numbers 13375003 (to J. Murata), 23770101 and 15K07207 (to N. Tanaka).

\section{References}

Aishwarya, K. \& Sabu, M. (2015). Boesenbergia pulcherrima and B. tiliifolia (Zingiberaceae) in India: Notes on the identity, variability and typification. Rheedea 25: 59-68.

Baker, J.G. (1890). Scitamineae. In: Hooker, J.D. (ed) The Flora of British India 6: 198-264. London: L. Reeve \& Co. 
Burtt, B.L. \& Smith, R.M. (1972). Key species in the taxonomic history of Zingiberaceae. Notes Roy. Bot. Gard. Edinburgh 31: 177-227.

Hundley, H.G. (1987). List of Trees, Shrubs, Herbs and Principal Climbers, etc. recorded from Burma with Vernacular Names, 4th Revised Ed. Rangoon: Forest Department, Swe Daw Oo Press.

Hundley, H.G. \& U Chit Ko Ko (1961). List of Trees, Shrubs, Herbs and Principal Climbers, etc. recorded from Burma with Vernacular Names, 3rd Ed. Rangoon: Superintendent., Govt. Printing and Stationary.

Kress, W.J., Prince, L.M. \& Williams, K.J. (2002). The phylogeny and a new classification of the gingers (Zingiberaceae): Evidence from molecular data. Amer. J. Bot. 89: 16821696.

Kress, W.J., DeFilipps, R.A., Farr, E. \& Kyi, Y.Y. (2003). A checklist of the trees, shrubs, herbs and climbers of Myanmar. Contr. U.S. Natl. Herb. 45: 1-590.

Kuntze, O. (1891). Revisio Generum Plantarum 2: 685. Leipzig: Felix.

Lace, J.H. (1912). List of Trees, Shrubs, Herbs and Principal Climbers, etc. recorded from Burma. Rangoon: Forest Department, CCF.

Mood, J.D., Prince, L.M., Veldkamp, J.F. \& Dey, S. (2013). The history and identity of Boesenbergia longiflora (Zingiberaceae) and descriptions of five related new taxa. Gard. Bull. Singapore 65: 47-95.

Mood, J.D., Trần H.Đ., Prince, L.M. \& Veldkamp, J.F. (2016). Boesenbergia siphonantha (Zingiberaceae) - A new record for Thailand and Vietnam. Gard. Bull. Singapore 68: $125-137$.

Rodger, A. (1922). List of Trees, Shrubs, Herbs and Principal Climbers, etc. recorded from Burma with Vernacular Names, Ed. 2. Rangoon: Forest Department.

Thiers, B. (continuously updated). Index Herbariorum: A global directory of public herbaria and associated staff. New York Botanical Garden's Virtual Herbarium. http://sweetgum. nybg.org/science/ih/ (accessed on 12 Jul. 2016).

Tong, S.Q. (1986). A new species of Boesenbergia from Yunnan. Acta Phytotax. Sin. 24: 323.

Wallich, N. (1829). Plantae Asiaticae Rariores 1: 22-23. London: Treuttel \& Wurz.

Wallich, N. (1832). A Numerical List of Dried Specimens of Plants in the East India Company's Museum, collected under the superintendence of Dr. Wallich, of the Company's Botanic Garden at Calcutta (The Wallich Catalogue). London: Wallich. 


\section{$2 \mathrm{BHL}$ Biodiversity Heritage Library}

Mood, John D. et al. 2016. "The genus Boesenbergia (Zingiberaceae) in Myanmar with two new records." The Gardens' bulletin, Singapore 68(2), 299-318. https://doi.org/10.3850/s2382581216000235.

View This Item Online: https://www.biodiversitylibrary.org/item/223196

DOI: https://doi.org/10.3850/s2382581216000235

Permalink: https://www.biodiversitylibrary.org/partpdf/229556

\section{Holding Institution}

Singapore Botanic Gardens, National Parks Board Singapore

\section{Copyright \& Reuse}

Copyright Status: In copyright. Digitized with the permission of the rights holder.

License: http://creativecommons.org/licenses/by-nc-sa/4.0/

Rights: https://biodiversitylibrary.org/permissions

This document was created from content at the Biodiversity Heritage Library, the world's largest open access digital library for biodiversity literature and archives. Visit BHL at https://www.biodiversitylibrary.org. 